\title{
LAND RIGHT'S APPLICATION IN ACCORDANCE WITH THE USE OF EXISTING SPACE IN MEDAN CITY
}

\author{
Ahmad Budinta Rangkuti*1 and Muhammad Yamin Lubis $\left.{ }^{*}\right)$ \\ *) Faculty of Law, University of Sumatera Utara \\ Jl.Universitas No.4 USU Campus, Medan 20155
}

\begin{abstract}
One of the tasks of the Ministry of Agrarian and Spatial Planning/National Land Agency of the Republic of Indonesia is to provide types of land rights in each region throughout Indonesia. The purpose of this study is aimed for the institution of the National Land Agency throughout Indonesia to provide land rights based on the type of land allocation and its usage. This is a normative legal study in which data were collected through library research with the support of empirical data from the Land Agency of Medan. The allocation system, a type of land zone division system, is utilized by the Municipal Land Affairs Office of Medan to establish land rights. Building rights are granted by the Land Agency when a zone has been allocated as a trading area, although in practice there are still a lot of lands used for residential purposes. The designation system for the granting of land rights assigned by the Municipal Land Affairs Office of Medan, based on Regional Regulation No. 2 of 2015, failed to uphold justice for the people of Medan that applied for the rights to the land under their name. Therefore, a more applicable system is the existing spatial system or a system based on the land's actual use in practice
\end{abstract}

Keywords: National Land Agency, spatial planning, allocation system, land use, spatial management

Abstrak: Salah satu tugas Kementerian Agraria dan Tata Ruang/Badan Pertanahan Nasional Republik Indonesia adalah memberikan jenis hak atas tanah di setiap daerah di seluruh Indonesia. Tujuan penelitian ini adalah agar instansi Badan Pertanahan di seluruh Indonesia dalam memberikan jenis hak atas tanah tersebut tidak hanya melihat peruntukannya saja, tetapi juga harus melihat penggunaan tanah tersebut. Studi ini merupakan kajian hukum normative dengan menggunakan data yang dikumpulkan dari tinjauan pustaka dan data empiris dari Badan Pertanahan Kota Medan. Sistem pembagian zona tanah di Kota Medan yang digunakan oleh Kantor Pertanahan Kota Medan dalam menetapkan hak atas tanah adalah sistem alokasi. Jika zona telah dialokasikan sebagai area perdagangan, hak tanah yang diberikan oleh Kantor Pertanahan adalah hak dalam menggunakan tanah untuk bangunan, meskipun di zona tersebut masih ada lahan yang digunakan untuk rumah tinggal. Sistem penunjukan untuk pemberian hak tanah oleh Kantor Pertanahan Kota Medan berdasarkan Peraturan Daerah No. 2 tahun 2015 belum mampu menegakkan keadilan bagi masyarakat Medan yang akan mengajukan hak kepemilikan atas tanahnya. Oleh karena itu, sistem yang lebih tepat adalah system tataruang (existing) atau suatu sistem yang berdasarkan penggunaan actual lahan di lapangan.

Kata kunci: Badan Pertanahan Nasional, tataruang, system alokasi, peruntukan tanah, pengelolaan lahan

\footnotetext{
${ }^{1}$ Corresponding author:

Email: budir1312@gmail.com
} 


\section{INTRODUCTION}

The State Rights to control the land, water, space and natural resources contained therein does not equal to its ownership. Indonesian citizens can own strong and full property rights. Such rights can be obtained under certain conditions following the provisions contained in the Agrarian Law and other regulations in the land management system (Ramadhani, 2018). The definition of 'owned by the state' is interpreted as public ownership, which means that 'State Ownership Rights' (SOR) as a form of legal relations between the state and agrarian resources are defined as public relations, not private resemblance to the relationship between the state and agrarian resources in previous colonial and feudal governments (Sitorus, 2016)

Indonesia that had been colonized by the Netherlands for 350 years adopts the European continental law brought by the Dutch originating from France (Penal Code). The continental European law that regulates the civil relationship is called civil law, which is enforced in Indonesia through codification meaning that the civil law prevailing in the Netherlands is fully implemented in Indonesia. This can be seen from the Dutch colonial law that is still valid today, namely the Civil Code, a civil law procedure that is applicable in Java and Madura (HIR) as well as in Sumatra and Bali (RBG). In the field of agrarian law, which is also part of civil law in Indonesia, namely agrarische wet, agrarische besluit whose legal provisions tended to benefit the Dutch colonial government was once applied. After the Dutch occupation ended, a national agrarian law based on customary law was issued in the form of Basic Agrarian Law (BAL) No. 5 of 1960.

If the provisions of Article 33 of the 1945 Constitution is analyzed further, specifically Paragraph 3, it can be said that the formal juridical basis used by the state through power exercised by the government to carry out the authority of attribution in controlling the land, water, space, and natural resources contained in it is to use them solely for the prosperity of the people. Because of the land is an important natural resource for the survival of humanity. Land does not only provide a place to live, but it also provides resources for the survival of humanity (Mandala, 2016).

The BAL has created an administrative arrangement of land rights that are valid for all regions of Indonesia in terms of rights to owned land. The implementation of legal arrangements in the agrarian sector, especially in the field of land, is also closely related to spatial planning and territory of land owned by every person/community group in Indonesia. Therefore, the government also undertakes legal efforts to regulate land use concerning spatial planning and territory in the Republic of Indonesia (Erwiningsih, 2009). The relationship between land and spatial arrangement is to optimize land utilization so that there can be an organized and ordered land stewardship in Indonesia while still being guided by spatial planning, thus creating harmony to land spatial stewardship in Indonesia.

The authority of attribution is the granting of government authority by legislators to the organ of government. Authority in controlling the land, water, space, and the natural resources contained therein is delegated by legislators to the Ministry of Agrarian and Spatial Planning/National Land Agency (MASP/NLA) as a government organ. Furthermore, the MASP/NLA Ministry gives delegations to provincial land office agencies and municipal district land offices to control the land, water, space, and natural resources contained therein as an extension of the Ministry of Agrarian and Spatial Planning (SP).

The issuance of National Law No. 26 of 2007 concerning Spatial Planning (SP) as a legal basis of spatial planning in Indonesia is currently the momentum for implementing a new concept of spatial and regional planning that is more planned, effective, and efficient in rearranging all spaces and regions covering the land, water, and space in the entire territory of the Republic of Indonesia. Spatial planning is a system consisting of spatial planning processes, spatial use, and control, following the provisions of Article 1 Paragraph 5 of the SP Law. The implementation of spatial planning includes regulation, fostering, implementation, and supervision.

Based on the provisions of Article 11 of the SP Law, the Government of Medan has made regional provisions of the legislation to carry out the implementation of spatial planning and land area in Medan. Provisions on the implementation of spatial arrangement and land territory are contained in the Regional Regulation of Medan City No. 2 of 2015 on Spatial Detail Planning and Zoning Regulation of Medan City in the years of 2015-2035. Article 1, Paragraph 20 of the No. 2 of 2015 Regional Regulation states that "Zoning Regulation is a provision that regulates the requirements of space utilization and 
its controlling provisions and is prepared for each block/allocated zone whose allocation is specified in detailed spatial planning".

Land use is a dominant function with special provisions regulated in a region, an allocated block, and/or a plot, following Article 1 Paragraph 21 of the No. 2 of 2015 Regional Regulation. The designation of a zone/ block/plot set by the Government of Medan through the Municipal Land Affairs Office toward the existing block of land can be classified into several zones/blocks/ plots. The designation of a zone based on its allocation failed to reflect a legal certainty and justice for people living in a zone that has residential areas. The people who use the land as a residence should be able to apply for a certificate of ownership.

The designation of a land zone that refers to the allocation pre-determined by the Medan City Government and the Municipal Land Affairs Office has created injustice in the community. This contradicts the fifth principle of Pancasila, namely Social Justice for All Indonesians and Article 28D Paragraph (1) of the 1945 Constitution which states, "Everyone is entitled to legal recognition, guarantee, protection and certainty, and equal treatment before the law ".

The implementation of spatial arrangement toward a zone/block/plot of land in Medan based on the unilateral designation of the Government of Medan and the Municipal Office of Land Affairs has caused delays in the process of applying for land rights for the people even though the use of the land is different from its determined allocation. The rights of the community have been neglected by the land designation system. Upon closer inspection, the use of existing principle with actual land use is considered more appropriate, because the people apply for their rights in accordance with the actual (existing) facts.

Guidelines for the use of the existing system state that a group of people applying for their land rights must have used the land in the field for residential purposes. If the land is used for residential houses, even if the zone has been designated for trade and service, the application to obtain a certificate of land and residential building ownership can still be processed legally, and should not be rejected by the Municipal Land Affairs Office.
The problem arising that needs to be solved lies in the fact that Indonesian citizens who apply for rights to their land are given building use rights. The type of right they should have is Property Rights. Consequently, this constitutes a violation of human rights as stated in Article 20, Article 21, and Article 22 of Basic Agrarian Law. In addition, inappropriate granting of rights also contradicts the Regulation of the Head of the National Land Agency (Perka BPN) Number 6 of 1998 concerning the Granting of Ownership Rights to Land for Residential Houses.

The application of land rights based on the existing system is considered compliant with the values of the fifth principle of Pancasila: Social Justice for All Indonesians. It is also compliant with values contained in Article 28D Paragraph 1 of the 1945 Constitution which essentially requires equal rights and obligations of all Indonesian Citizens without exception before the law (Fitriani, 2014) so that the people of Indonesia applying for land rights will receive justice, certainty in the law, and expediency. How can granting land title as a residential home based on the allocation system so that it does not conflict with spatial planning and human rights?

\section{METHODS}

This research uses a doctrinal legal method (normative law research method). This method, namely law research which is conceptualized and developed based on certain doctrines. Ibrahim (2005) defines normative legal research as a scientific research procedure for uncovering the truth based on the normative side of legal scholarship logic.

Research, in general, distinguishes between the data obtained directly from the community (referred to as primary data), and those from library materials (referred to as secondary data). This research used the normative law method. In the study of normative laws, library materials serve as basic data, which are classified as secondary data. It has a very wide scope, covering personal letters, diaries, books, and official documents filed by the Government. Such data is generally characterized by ready-made forms. The contents have been established and filled by previous researchers and can be obtained without time and place boundaries. 
Based on its binding strength, the secondary data materials for this normative law was divided into (a) primary legal materials, which consists of laws and regulations such as the 1945 Constitution, Basic Agrarian Law, Spatial Laws, up to the implementing regulations, and (b) secondary legal materials, which consists of the views of experts in books and journals. The primary, secondary, and tertiary legal materials were obtained through literature studies. All the data were then analyzed qualitatively, profoundly, holistically, and comprehensively.

This study uses a normative juridical method which includes research on legal principles. In normative law research, research on legal principles is applied to legal principles that contain guidelines for behaving or acting inappropriately. Such research may be conducted mainly on primary and secondary legal materials, as long as they contain legal rules.

There are only restrictive passages that are commonly found in the chapters of the general provisions and legislation. Research on the principles of law is a philosophical study since the principles of law are the ideal elements of it. The nature of this research was a qualitative normative legal study, using both conceptual and statute approaches. The research was conducted in Medan, specifically at the Municipal Land Affairs Office, from April to June 2018.

The research applies the Juridical Approach, which deals with research on laws and other regulations that govern the granting of land rights. In addition, the case approach is also used through analysis of cases related to legal issues; and conceptual approaches relating to juridical concepts contained in Basic Agrarian Law and the related regulations therein. The implementation of this allocation system has an impact on the existence of the neglected rights of Indonesians. In obtaining land rights, the applicant obtains the building right to the land in a trading and service area even if it is used as a residential house.

\section{Hypothesis}

The granting land title as a residential home based on an allocation system so that it does not conflict with spatial planning and human rights must be implemented following the Basic Agrarian Law and the Regulation of the Head of the National Land Agency (Perka
BPN) Number 6 of 1998 concerning the Granting of Ownership Right to Land for Residential Houses. Meanwhile, to check the actual practice, it should be carried out based on the Regulation of the Head of BPN Number 7 of 2007 concerning the Land Inspection Committee.

\section{RESULTS}

The 1945 Constitution is a ground norm that explicitly and implicitly contains basic views and values from all provisions of the prevailing laws and regulations in Indonesia. It is a political as well as an economic constitution, and also a social constitution, in which the entirety of the 1945 Constitution is an elaboration of the values contained in the Pancasila as a fundamental norm to the Republic of Indonesia (Susilo, 2011).

As a Basic Law, the 1945 Constitution within the framework of the rules or the hierarchy of applicable legal norms in Indonesia occupies a high position, and all legislation and rules below it may not conflict with it. As a law basis, the 1945 Constitution is a source of written law. Thus every legal product such as law, government regulation, presidential regulation, or even every government action or policy must be based on and sourced from a higher regulation, which ultimately all of these laws must be accounted for following the provisions of the 1945 Constitution and the Pancasila as its predecessor as the source of all sources of state law. In such a position, the 1945 Constitution is in the framework of the order of laws or hierarchy of laws and regulations in Indonesia following the provisions of Law No. 12 of 2011 which occupies the highest position. It also has a function as a means of control, in the sense that it controls whether lower legal norms are following higher legal norms, and in the end, whether the legal norms are contrary to its provisions (Iriani, 2011). The provisions of Article 7 Paragraph (1) Law No. 12 of 2011 state that, "Types and hierarchies of laws and regulations consist of:

a. The 1945 Constitution of the Republic of Indonesia

b. Decree of the People's Consultative Assembly (MPR)

c. Substitute Government Laws/Regulations

d. Government Regulations

e. Presidential Decree

f. Provincial Regulations

g. District/city regulations 
From the provisions of Article 7 Paragraph (1) of Law No. 12 of 2011 above, it can be said that the 1945 Constitution is not the only or the whole basic law, but is only part of it, namely the written basic law. Besides that, there are still other basic laws, namely unwritten basic laws. Unwritten basic laws are the basic rules that arise and are maintained in the practice of administering the state - although not written, it is still implemented as a convention. Although a convention is also a basic law (unwritten), it must not conflict with the 1945 Constitution. The convention is a complementary rule or a filler of the legal vacuum that arises and is maintained in the practice of state administration because it is not contained in the 1945 Constitution (Rumokoy, 2010). Functions of the Basic Law in a legal state are as follows(Chandranegara, 2014): The highest form of regulation; and as a legal source for all applicable regulations of the country concerned.

Data received from the Land Affairs Office was problematic in which the land was used as a residence but the Land Affairs Office designated building land rights. The use of an allocation system in the establishment of land rights based on the concept of spatial and environmental order with the legal basis of Perda (Regional Regulation) No. 2 of 2015 is considered inappropriate because it does not reflect the principle of justice for the people of Medan who apply for land rights under their control in a zone of territory that has been determined by the Municipal Land Affairs Office based on the allocation system (Sarwanto, 2014).

The data in the Table 1 shows that granting land rights to Indonesian citizens in Medan City is inappropriate. Rights that should be given are property rights, but they are given building land use rights. This is against human rights, laws, and regulations. There is no single regulation that explicitly states that granting residential house rights should be based on the spatial designation. So, if a territory has been designated as a trading zone and the people living in the trading zone use their land for residence, they can apply for ownership rights. In this case, the land officers should conduct legal proceedings to issue a certificate of ownership over the land in which the house is located (Sarwanto, 2014).

For zones that have been designated as a trading zone, people who apply for land rights can only be given a certificate of building use rights. This reflects injustice for the people, who in good faith, applied for the rights to the land which is used as a place to live. Therefore, the allocation system based on the spatial concept used in the designation of zoning areas in Medan is not appropriate and can cause legal uncertainty and public disruption. Therefore, it is more appropriate to use territory zoning based on the existing guidelines, namely actual use of the land in the community. In this case, if the applicant uses the land as a residential house as evidenced by the presence of a residential building, building permit as a residence, or a letter from the neighborhood leader that explains that the land is used as a residential house, not a business building, the city land agency shall grant the property rights.

The purpose of establishing this Basic Agrarian Law is explained in Article 2 Paragraph (3), namely that the authority that derives from the controlling rights of the State is used solely for the prosperity of the people, in terms of happiness, prosperity, and independence of the Republic of Indonesia and its people. Furthermore, in the provisions of Article 2 Paragraph (4) of the Basic Agrarian Law, it is stated that "The control rights can be authorized to autonomous regions and customary law communities are only needed and do not conflict with national interests according to government regulations. Article 11 of this law can be referred to show that this Basic Agrarian Law is biased towards the people, namely, "That the legal relationship between people, including legal entities with land, water, and space and the authority that comes from legal relations will be regulated to achieve the objectives mentioned in Article 2 Paragraph (3) of the Basic Agrarian Law and will prevent ownership of the lives and work of others that exceed the limits ".

Furthermore, Article 13 of the Basic Agrarian Law states that The government strives so that ventures in the agrarian field are regulated in such a way as to increase the production and prosperity of the people referred to in Article 2 Paragraph (3) and ensures that every Indonesian citizen lives in accordance with human dignity, both for themselves and their families. The government also prevents ventures in agrarian fields from private monopoly organizations and individuals that can only be carried out by law so that The government strives to advance certainty and social security including labor, in ventures in the agrarian field. 
Table. 1. Implementation of Perda No. 2 of 2015

\begin{tabular}{|c|c|c|c|c|c|}
\hline Name & $\begin{array}{c}\text { Surface Area } \\
\left(\mathrm{m}^{2}\right)\end{array}$ & $\begin{array}{l}\text { Location of Village/ } \\
\text { District Land }\end{array}$ & Allocation & Utilization & Land Rights \\
\hline Dra. Iriani Napitupulu & 247 & $\begin{array}{c}\text { Medan Tenggara/Medan } \\
\text { Denai }\end{array}$ & Trading & $\begin{array}{l}\text { Residential } \\
\text { House }\end{array}$ & $\begin{array}{c}\text { Building } \\
\text { Right Title }\end{array}$ \\
\hline Johanes Sitorus & 52 & Darat/Medan Baru & Trading & $\begin{array}{l}\text { Residential } \\
\text { House }\end{array}$ & $\begin{array}{l}\text { Building } \\
\text { Right Title }\end{array}$ \\
\hline Iriani Fahmi & 816 & $\begin{array}{c}\text { Tangkahan/Medan } \\
\text { Labuhan }\end{array}$ & Industry & $\begin{array}{l}\text { Residential } \\
\text { House }\end{array}$ & $\begin{array}{l}\text { Building } \\
\text { Right Title }\end{array}$ \\
\hline
\end{tabular}

From the various basic provisions, Basic Agrarian Law No. 5 of 1960 also determines the rights of the people to the land that can be divided into (Ginting, 2013): Property rights (Articles 20-27), Use rights (Article 28-34), Building rights (Articles 35-40), Right to use (Articles 41-43), Rental rights for buildings (Articles 44-45), The right to open land and collect forestry products (Article 46), Temporary land rights (Article 53) namely mortgage rights, profit-sharing business rights, hitching rights, agricultural land leasing rights, Customary rights. BAL also mention other rights not included in the rights mentioned above will be determined by the law and temporary rights.

In addition to the aforementioned rights, there are rights to other parts of the land which consist of water use, maintenance, and fishing rights (Article 47) and space usage rights (Article 48). With the enactment of the Basic Agrarian Law (BAL), the government begins to organize and control the structure of Indonesian land ownership based on customary law because during the colonial period the pattern of land ownership was very unfair and irregular. Thus, it can be said that the right to control does not mean ownership. Property rights are strong and full and can be possessed by Indonesian citizens, whose ownership rights can be obtained with certain conditions according to the provisions contained in the BAL and other laws and regulations in the land sector (Imran, 2013). Legal arrangements in the agrarian sector, especially in the land sector, which relate to the rights to land owned by every Indonesian citizen who, in the period after independence, has been regulated by BAL No. 5 of 1960, has created an administrative arrangement of land rights that are valid for all regions of Indonesia in terms of land rights. The implementation of legal arrangements in the agrarian sector, especially for land, is also closely related to spatial planning and territory of land owned by every person/community group in Indonesia. Therefore the government of the Republic of Indonesia also makes legal efforts to regulate land use about spatial planning and territories in the Republic of Indonesia (Zuhri, 2012). Article 2 of BAL No.5 of 1960 relating to the concept of spatial planning in the land sector states:

1. Based on the provisions in Article 33 Paragraph (3) of the Constitution and matters referred to in Article 1 , the land, water, and space, including the natural resources contained therein at the highest level are controlled by the State, as an organization of power of all people.

2. The controlling rights of the State referred to in Article 33 Paragraph (1) of this article authorize and:

a. regulate and administer the designation, use, supply, and maintenance of the land, water, and space;

b. determine and regulate legal relations between people and land, water, and space,

c. determine and regulate legal relations between people and legal actions concerning the land, water, and space.

3. The authority that derives from the controlling rights of the State in Article 33 Paragraph (2) of this article is used to solely achieve the prosperity of the people, in terms of happiness, prosperity, and independence in a sovereign, just, and prosperous Indonesian law and society.

4. The control rights of the aforementioned State can be delegated to the autonomous areas and customary law communities as long as it is needed and is not in conflict with national interests, according to the provisions of Government Regulations.

The basic concept of the next spatial arrangement contained in the BAL is as contained in Articles 14 and 15. Article 14 of the BAL states that: By keeping in mind the provisions in Article 2 Paragraph (2) and (3), Article 9 Paragraph (2), and Article 10 Paragraph (1) and (2), the Government in the framework of 
Indonesian socialism, devise a general plan regarding inventory, designation, and the usage of the land, water, and space and the natural wealth contained in it: a) for State purposes; b) for worship and other sacred purposes, following the basis of the One Godhead; c) for the centers of community life, social, cultural, and other welfare; d) to develop agricultural, livestock, and fisheries production and in line with that; e) for the need to develop industries, transmigration, and mining.

The basis of the birth of the provisions on spatial planning which is guided by the provisions of Articles 14 and 15 of the BAL is due to the provisions of Articles 14 and 15 of the BAL mandating the regulation and use of the land, water, and space as well as natural resources contained in them so that they can be used orderly and regularly according to the designation and use so that harmony between land stewardship and appropriate space management arises in the area has been set for land use. According to conventional legal theory, the purpose of the law is to realize legal certainty (rechtszekerheid), justice (rechtgerechtigeheid), and expediency (rechtsulititeit) (Wijayanti, 2013).

In his book, "Inleiding tot de studie vanhetnederlandserecht", Apeldorn (1986) stated that the purpose of the law is to regulate order in society peacefully and fairly. To achieve legal peace, a just society and legal certainty and justice must be created by balancing interests that conflict with one another. According to W. Friedman, a law must provide equal justice to all people/parties, even though there are differences between these individuals (Friedman, 1993). From the description above, the theory used in this study is a legal theory, a positive legal theory from Hart's, Gustav Radbruch's theory of legal certainty, and the theory of justice from Jhon Rawls.

The positive legal theory according to Hart's is a theory stating that there are no provisions of legislation other than in a written form that is ratified by an authorized body and applies in that society. Written regulations made by the competent body must be seen in the contents of the regulation, whether or not it is beneficial to the people it regulates. Hence, the birth of the regulation will create an order of a legal relationship in the community. Besides, the contents of the applied regulations must be felt by the community to regulate the legal relations that occur among fellow members of the community in a fair and balanced manner to create order and legal certainty in carrying out legal actions (Gunaryo, 2007).

If the benefits of the laws and regulations are not felt by the community, then a legal breakthrough can be applied to the applicable laws and regulations, to find a benefit from the legislation that has been issued. Legal breakthroughs carried out by authorized institutions are legitimate in order to find a benefit from legislation that has been applied but are incomplete in terms of regulating certain legal actions that occur and develop in the life of the people they regulate. Therefore, according to Hart's legal breakthroughs on the void of legal arrangements contained in the applicable laws and regulations, they are legal and have legal powers that are binding for the parties and can be carried out properly (Latipulhayat, 2016).

The theory of legal certainty from Gustav Radbruch states that there are 4 basic things from the meaning of legal certainty: a) The law must be in the form of positive law (written), in the form of constitutions and other regulations; b) The law is based on facts or laws; c) The distinctness of the fact must be formulated to avoid mistakes in the meaning besides being easy to implement; d) Positive law cannot be volatile because it will cause ambiguity (Radbruch, 1963).

Gustav Radbruch's opinion is based on his view that legal certainty is a certainty about the law itself. Legal certainty is a product of law or more specifically from the legislation. Based on this opinion, according to Gustav Radbruch, positive laws governing human interests in the society must always be adhered to, even though the positive law is unfair.

Certainty is a feature that cannot be separated from the law, especially for written legal norms. Law without the value of certainty will lose meaning because it can no longer be used as a guideline for everyone. Certainty itself is referred to as one of the objectives of the law. Historically, the discussion about legal certainty was a conversation that had arisen since the idea of the separation of powers from Montesquieu.

The order of society is closely related to certainty in the law, because an order is the core of certainty itself. Ordering causes people to live with certainty so that they can carry out activities that are needed in the community. 
Legal certainty is a guarantee that the law is implemented, that those who are entitled according to the law can obtain their rights, and that the verdict can be implemented. Although legal certainty is closely related to justice, the law is not synonymous with it. Law is general, binding everyone, generalizing, while justice is subjective, individualistic, and not generalized.

Legal certainty is the implementation of the law following its contents so that the community can ensure that the law is implemented. In understanding the value of legal certainty, it must be considered that the value has a close relationship with positive legal instruments and the role of the state in actualizing it in positive law.

Justice theory popularized by John Rawls (Ya'kub, 2004) has set the principles of justice as shown in the following:

1. Maximizing independence. This limitation on independence is only for the sake of independence itself.

2. Equality for all people, both equality in social life and equality in the form of utilization of natural resources (social food). Restrictions, in this case, can only be permitted if there is a possibility of greater profits.

3. Equality of opportunity for honesty, and the elimination of inequalities based on birth and wealth (Rawls, 2006).

Rawls believes that if there is a conflict, the Equal Liberty Principle must be prioritized over other principles, and the Equal Opportunity Society must be prioritized over the Multiple Differences.

In implementing the theory of justice, Rawls emphasizes efforts to formulate principles that govern the distribution of rights and obligations among all members of society. Emphasis on the issue of rights and obligations, which is based on a concept of justice for social cooperation, shows that Rawls's theory of justice focuses on how to distribute rights and obligations equally in a society so that everyone has the opportunity to benefit from them and actually, to bear the same load. Therefore, to guarantee the distribution of equal rights and obligations, Rawls also emphasizes the importance of a fair agreement among all members of the community. Only a fair agreement can encourage social cooperation.
Fair agreements are the key to understanding the formula for justice. Rawls views that a fair agreement can only be achieved with impartial procedures. Only with an impartial procedure can the principles of justice be considered fair. Therefore, for Rawls, justice as fairness is "pure procedural justice". In this case, what is needed by the community in a statutory regulation is the concept of justice described in a fair procedure to guarantee a fair outcome.

A fair procedure for the birth of decisions that everyone can accept is fair. The fair procedure can only be fulfilled if there is a climate of deliberation that allows the birth of decisions that can guarantee a fair distribution of rights and obligations. Rawls emphasizes the importance of all parties involved in the deliberation process to choose the principles of justice, in an initial condition which he called "the original position".

Rawls formulates the two principles of justice as follows: 1) everyone must have equal rights to the broadest basic freedoms, as much as the same freedom for all people; 2) socio-economic inequality must be arranged in such a way that (a) is expected to benefit the most disadvantaged people, and (b) all positions and occupations are open to everyone.

Thus, to ensure the effectiveness of the two principles of justice, Rawls emphasizes that both must be arranged in an order called serial order or lexical order. With this arrangement, he emphasizes that basic rights and freedoms cannot be exchanged for social and economic benefits. This means that the second principle of justice can only get a place and be applied if the first principle of justice has been fulfilled. In other words, the implementation and execution of the second principle of justice must not conflict with the first principle. Therefore, basic rights and freedoms in this particular concept of justice have a top priority on social and economic benefits.

Restrictions on rights and freedoms are only allowed insofar as they are done to protect and secure the implementation of freedom itself. That means, it is necessary to accept an institutional arrangement of the practices of freedom so that the implementation of freedom does not endanger the freedom that is truly the right of everyone. 
The second principle of justice requires that inequality in achieving social and economic values is allowed if it continues to open opportunities for other parties to get benefits similarly. Therefore, inequality in obtaining social and economic values does not always have to be understood as injustice. The essence of the second principle of justice lies precisely on this side.

Although a zone has been designated as a trading and industrial zone, it does not mean that the land office cannot issue a certificate of ownership to the land, provided that the land is truly used as a place to live or home for the community (Ilhamdi, 2016).

In this case, the land agency does not violate the spatial layout and the community can obtain rights to the land following its use. A statement of the applicant must be made before a notary which shows that the residence is not a place of business, and if the use of this land is changed from a residential place to other purposes (i.e. business, office, industry, trade) then the certificate of ownership of this land automatically becomes a right of use for the building. This will not make any sue to the land agency of decreasing the right from Property Right to the Building Rights Title. This statement clarifies that the legal authority of the city land agency should make notes on the certificate of the applicant's statement, after receiving a building permit or certificate from the neighborhood leader.

The inclusion of a spatial directorate within the authority of the National Land Agency implies that land use must pay attention to certain aspects such as regularity, naturally beautiful, suitability, and also land capability. The granting of land rights must also pay attention to the allocation of land use for the benefit of advancing the economic sector. Thus, if the government needs the land for investment purposes, the Regional Government can easily determine the mapped location. Also, good spatial planning will support government policies in a measured and oriented regional development so that the results can be enjoyed by the whole community.

\section{Managerial Implications}

The managerial implication of the research above can be applied following the Medan Regional Regulation Number 2 of 2015. The Regional Regulation states that Medan consists of neighborhoods. This is a good condition as the Medan Land Affairs Office can issue land rights based on the land use. Should the land be used for a residential purpose, supported with the data such as building permits or a clarification letter from the village/neighborhood head, the ownership rights can be issued based on the land's existing condition. Hence, justice can be attained.

\section{CONCLUSIONS AND RECOMMENDATIONS}

\section{Conclusions}

Based on the above description relating to the land usage system or guidelines for establishing a zone under the spatial concept, it is clear that the existing land usage system is more appropriate to establish zones in an area rather than the allocation system that can lead to injustice and cause a commotion in the community. Applications of land rights submitted to the land agency are currently unable to be processed since such applications are made to the land designated as a trading or industrial zone, even such applications have declared that such land is used for residential purposes.

\section{Recommendations}

Research relating to delegating spatial planning authority into BPN is still limited in quantity. In the future, there should be plenty of inputs that can be derived from some research projects in land use based on spatial planning. The government should issue the regulation of the Ministry of Agrarian and Spatial Planning/National Land Agency which regulates the land rights process. If this is achieved, all sectors will gain benefits, justice, and certainty. For example, investors can find a potential business location. Regional governments can also determine the value of land and building tax automatically to be paid into the State treasury.

\section{REFERENCES}

Apeldoorn L J Van. 1986. Pengantar Ilmu Hukum, Cetakan XIII. Jakarta: Pradnya. Paramita

Chandranegara I S. 2014. Fungsi Falsafah Negara Dalam Penerapan Konsep Negara Hukum. Jurnal Cita Hukum 1(1): 53-66

Erwiningsih W. 2009. Pelaksanaan pengaturan hak menguasai negara atas tanah menurut UUD 1945. Jurnal Hukum 16: 118-136 
Fitriani E D. 2014. Implementasi kebijakan tata ruang wilayah dalam mewujudkan pembangunan kota berkelanjutan. Jurnal Administrasi Publik 2(2):217-223.

Friedman W. 1993. Teori dan Filsafat Hukum Dalam Buku telaah Kritis Atas Teori-Teori Hukum. Trans. Muhammad Arifin Jakarta: Raja grafindo Persada

Gunaryo A. 2007. Beberapa catatan tentang konsep Hukum H.L.A. Hart dalam Buku the Concept of Law. Jurnal Hukum Progresif 3(1)

Ibrahim J. 2005. Teori dan Metode Penelitian Hukum Normatif. Malang: Banyumedia Publishing.

Ilhamdi. 2016. Tinjauan yuridis tentang hak atas tanah perusahaan di kawasan industri di Indonesia. De Lega Lata 1(2):329-348

Imran S Y. 2013. Fungsi Tata Ruang Dalam Menjaga Kelestarian Lingkungan Hidup Kota. Jurnal Dinamika Hukum 13(3):457-467.

Iriani D. 2016. Hukum sebagai alat kontrol sosial dan sistem supremasi penegakan hukum. Justicia Islamica : Jurnal Kajian Hukum dan Sosial 8(1):139-159

Latipulhayat A. 2016. Hart. Padjadjaran Jurnal Ilmu Hukum 3 (3): 655-666.

Mandala MM. 2016. Pelaksanaan Pendaftaran Hak Milik Atas Tanah Melalui Proyek Operasi Nasioanal Agraria (PRONA) dalam Rangka Mewujudkan Tertib Administrasi di Kabupaten Barito Timur. Jurnal Hukum UAJY.

Radbruch G. 1961. Einfuehrung In Die Rechtswissenchaft. Stuttgart: Koehler Verlag

Ramadhani R. 2018. Korelasi Hukum Antara Pengaturan Zonasi Wilayah dengan Pendaftaran
Hak Milik atas Tanah di Kota Medan. Jurnal EduTech 4 (2): 40-49.

Rawls J. 2006. Teori Keadilan. Trans. Muhammad Arifin. Jakarta: Raja Grafindo Persada

Rumokoy N K. 2010. Peranan Konvensi Ketatanegaraan dalam Pengembangan Hukum Tata Negara Indonesia. Jurnal Hukum Unsrat XVIII(4):1122.

Sarwanto WM. 2014. Konsep Tata Ruang dan Tata Lingkungan Berdasarkan UU RI No. 26 Tahun 2007 Tentang Penataan Ruang. Jakarta: Refika Aditama.

Sitorus O. 2016. Penataan Hubungan Hukum Dalam Penguasaan, Pemilikan, Penggunaan, Dan Pemanfaatan Sumber Daya Agraria (Studi Awal terhadap Konsep Hak Atas Tanah dan Ijin Usaha Pertambangan). Jurnal Bhumi 2(1):1-11.

Susilo A B. 2011. Penegakan Hukum Yang Berkeadilan Dalam Perspektif Filsafat Hermeneutika Hukum: Suatu Alternatif Solusi Terhadap Problematika Penegakan Hukum di Indonesia. Jurnal Perspektif XVI (4):214-226.

Wijayanti W. 2013. Eksistensi Undang-Undang Sebagai Produk Hukum dalam Pemenuhan Keadilan Bagi Rakyat (Analisis Putusan Mahkamah Konstitusi Nomor 50/PUU-X/2012). Jurnal Konstitusi 10(1): 179-204.

Ya'kub M. 2004. Agenda Neoliberal Menyusup Melalui Kebijakan Agraria di Indonesia. Jurnal Analisis Sosial 9(1):47-64.

Zuhri M. 2012. Aspek Hukum Perencanaan Tata Ruang Kawasan Perkotaan di Indonesia. Kanun Jurnal Ilmu 14 (58): 485-494 